\title{
Yielding and Heavy Metals Accumulation in the Biomass of Grass Cultivated in Substrata with the Participation of Municipal Sewage Sludge and Green Waste Compost
}

\author{
Teodor Kitczak ${ }^{1}$, Anna Kiepas-Kokot ${ }^{2}$, Henryk Czyż ${ }^{1 *}$ \\ ${ }^{1}$ Western Pomeranian University of Technology in Szczecin, Faculty of Soil Science, \\ Grassland Science and Environmental, 71-434 Szczecin, ul. Słowackiego 17, Poland \\ ${ }^{2}$ Western Pomeranian University of Technology in Szczecin, Faculty of Ecology, Environmental \\ Protection and Development, 71-434 Szczecin, ul. Słowackiego 17, Poland
}

Received: 6 November 2015

Accepted: 22 April 2016

\begin{abstract}
During a six-year study on the influence of sewage sludge and green waste compost (in a dose of $20 \mathrm{Mg}$ TS $\cdot \mathrm{ha}^{-1}$ ) on yielding and heavy metals accumulation, Festuca arundinacea lawn mixture was used, consisting of $60 \%$ Festuca arundinacea of type Asterix $+15 \%$ Poa pratensis of type Opal $+15 \%$ Festuca rubra of type Areta $+10 \%$ Lolium perenne of type Pimperal. The subject of the study was the effect of these materials on yielding, changes in species composition of the sward, and the contents of copper, nickel, lead, and zinc in the aboveground parts of plants. The materials varied according to the fertilizing value and heavy metals content. Sewage sludge was rich in fertilizing components but also highly contaminated with heavy metals. Green waste compost contained large amounts of sand and the content of metals was slightly higher than in the subsoil to which it had been incorporated. The studied materials were found to have a stimulative effect on yielding plants. Yields obtained under the influence of sewage sludge and compost were similar. Changes in the species composition of the sward were connected to the durability of particular grass species used in the mixture. Despite the varied loads of heavy metals that were incorporated into soil with the used materials, they did not cause any significant increase of metals content in substratum, with the exclusion of copper incorporated into soil with sludge. Loads of metals incorporated into soil with sludge caused a significant increase of nickel and zinc in the aboveground parts of grass compared to the content of these metals in other variants of the experiment. The study found varied levels of metals uptake from soil by plants. The substratum with metals-contaminated sewage sludge demonstrated the highest uptake.
\end{abstract}

Keywords: municipal sewage sludge, green waste compost, lawn mixture, heavy metals, phytoremediation

*e-mail: Henryk.Czyz@zut.edu.pl 


\section{Introduction}

Organic fertilization of grassland is not common because of, among other things, an insufficient amount of natural and organic fertilizers, mainly manure on farms and the priority of their use on arable lands [1]. Decreasing livestock production and the decline in the amount of natural fertilizers may be balanced with the growing amount of sewage sludge produced in the plants for wastewater treatment and with the compost from green waste processing plants (mainly in composting facilities). The organic material produced there should find its place in biomass production [2], which is a more rational method of management than the previous, more commonly applied method of disposal by storage, or the expanding thermal disposal in incineration plants and co-incineration plants. One of the obstacles against the common use of waste (including sewage sludge) as fertilizer is the high diversity of components in different kinds of waste and even among their parts. This diversity includes both fertilizer components as well as those limiting its usability, such as heavy metals. The diversity causes practical difficulties in using waste in the appropriate fertilization doses. Often, the physical form of waste (liquid, clammy) and the odor are the deterrents against its application [3]. Also, the adverse microbiological parameters can be an obstacle against its use as a fertilizer [4].

Compared to annual crops, grassland plants, including lawns, are characterized by a high uptake rate of nutrients introduced into substrata with sludge, and they ensure the continuity of soil cover [5-9]. The aim of this paper was to evaluate the influence of soil-applied municipal sewage sludge and green waste compost on yielding Festuca arundinacea lawn mixture and the accumulation of heavy metals in grass biomass to decide on the effectiveness of metals extraction from cultivated substrata.

\section{Materials and Methods}

Our research was conducted in 2004-09 on subsoil of poor clayey sand of anthropogenic origin. A single-factor experiment was established in a randomized block design in three replications. The researched factor was the type of applied organic material:

- Control - subsoil.

- Municipal sewage sludge (rich in organic matter and fertilizer components with high heavy metals content).
- Green waste compost (poor in organic matter and fertilizer components with low heavy metals content).

The experiment used municipal sludge with a high content of heavy metals. The application of such municipal sludge in the cultivation of grasses was aimed at determining the response of studied grass species to high concentrations of metals in the growing medium, and the level of their collection and accumulation of metals in plant tissues. High tolerance in studied grasses on the heavy metals in the soil indicates the possibility of their use for the treatment of soils near the road using phytoextraction of metals.

The sludge used in the experiment originated from the municipal wastewater treatment plant in Recz, Poland, to which residential wastewater and pretreated industrial sewage from the local electroplating plant is fed by the sewage network. The flow of sewage from the electroplating plant causes an increase in the contents of copper, nickel, lead, and zinc in sewage and then in sludge (Table 2). The sludge used for the experiment had been mechanically dewatered and stabilized in accordance with the technology used in the plant in Recz. The green compost used in the experiment had been produced from waste (mown grass, leaves, twigs, and pine cones) obtained from the greenery of Dolna Odra Power Plant in Nowe Czarnowo. In the characteristics of this material (Table 1), one's attention is drawn to the low content of organic matter caused by a large amount of sand in the green waste used for compost production. Before composting, the waste had been mechanically ground and enriched with urea $\left(2 \mathrm{~kg} \cdot \mathrm{m}^{3}\right)$. The compost had been produced using the heap composting method.

The material used in the experiment (sludge and green waste compost) was soil-applied in autumn 2003 in a dose of $20 \mathrm{Mg} \mathrm{TS} \cdot \mathrm{ha}^{-1}$ and mixed with $10 \mathrm{~cm}$ layer of subsoil. Much higher loads of metals, especially copper, nickel, and zinc, were incorporated into the soil with sludge than with compost. The content of heavy metals in compost was significantly higher than in the subsoil on which the experiment was performed (Table 2).

Festuca arundinacea lawn mixture used in the experiment consisted of $60 \%$ Festuca arundinacea of type Asterix $+15 \%$ Poa pratensis of type Opal $+15 \%$ Festuca rubra of type Areta $+10 \%$ Lolium perenne of type Pimperal. The seeds of grass were sewn in the first decade of April 2004, using the standard of sowing $2 \mathrm{~kg} \cdot 100 \mathrm{~m}^{-2}$. In the first year of the experiment no mineral

Table 1. Basic characteristics of the materials used in the experiment.

\begin{tabular}{|c|c|c|c|c|c|c|c|c|}
\hline \multirow{2}{*}{ Specification } & $\begin{array}{c}\text { Organic } \\
\text { C }\end{array}$ & $\begin{array}{l}\text { Organic } \\
\mathrm{N}\end{array}$ & $\begin{array}{c}\text { Organic } \\
\mathrm{S}\end{array}$ & \multirow[t]{2}{*}{$\mathrm{C}: \mathrm{N}$} & $\begin{array}{c}\text { Organic } \\
\text { matter }\end{array}$ & \multicolumn{2}{|c|}{$\mathrm{pH}$ in } & $\begin{array}{l}\text { Electrical } \\
\text { conductivity }\end{array}$ \\
\hline & \multicolumn{3}{|c|}{$(\%)$} & & $(\%)$ & $\mathrm{H}_{2} \mathrm{O}$ & $\mathrm{KCl}$ & $\left(\mu \mathrm{S} \cdot \mathrm{cm}^{-1}\right)$ \\
\hline Subsoil & 3.00 & 0.10 & - & $30: 1$ & 4.27 & 7.92 & 7. 65 & 170.7 \\
\hline Sewage sludge & 22.30 & 2.60 & 0.50 & $8.6: 1$ & 45.40 & 6.10 & 6.00 & $2,317.7$ \\
\hline Green waste compost & 9.70 & 1.07 & 0.06 & $9.1: 1$ & 17.60 & 5.98 & 5.83 & $2,448.0$ \\
\hline
\end{tabular}


Table 2. Heavy metals contents in the material used in the experiment and loads of metals incorporated into susbstrata*.

\begin{tabular}{|c|c|c|c|c|c|}
\hline \multirow{2}{*}{ Metals } & \multicolumn{3}{|c|}{ Content $\left(\mathrm{mg} \cdot \mathrm{kg}^{-1}\right)$ in: } & \multicolumn{2}{c|}{ Load $\left(\mathrm{kg}^{\left.-\mathrm{ha}^{-1}\right)}\right.$ incorporated into soil with: } \\
\cline { 2 - 6 } & soil & sludge & compost & 40 & compost \\
\hline $\mathrm{Cu}$ & 16.6 & $1,995.5$ & 25.7 & 17 & 0.51 \\
\hline $\mathrm{Ni}$ & 10.9 & 844.0 & 24.5 & 3 & 0.49 \\
\hline $\mathrm{Pb}$ & 15.5 & 143.8 & 24.3 & 46 & 2.49 \\
\hline $\mathrm{Zn}$ & 81.7 & $2,827.6$ & 126.8 & & 2.54 \\
\hline
\end{tabular}

*loads of metals incorporated with sludge and compost in a dose of $20 \mathrm{Mg} \cdot \mathrm{ha}^{-1}$

fertilizing was applied. In subsequent years (2005-09) on all plots the following uniform mineral fertilization was applied: $60 \mathrm{~kg} \mathrm{~N}$ (30 kg early spring and $30 \mathrm{~kg}$ in the $3^{\text {rd }}$ week of June), $40 \mathrm{~kg} \mathrm{P}_{2} \mathrm{O}_{5}$, and $60 \mathrm{~kg} \mathrm{~K}_{2} \mathrm{O}$ in early spring.

The detailed studies included the assessment of annual yield (representing total yields of individual lawn-mowing dates), the analysis of species composition changes in the sward, and the content of selected heavy metals in the grass biomass.

Soil, sewage sludge and green waste compost were subjected to chemical analyses, which included: elemental composition (Corg, Nog, Sog., determined by the direct method on elemental analyzer), organic matter content (incandescence method), $\mathrm{pH}$ (potentiometric measurement of $\mathrm{pH}$ in $\mathrm{H}_{2} \mathrm{O}$ and $\mathrm{KCl}, 1: 2,5 \mathrm{~m} / \mathrm{V}$ after $24 \mathrm{~h}$ of extraction) and electrical conductivity (conductometrically in $\mathrm{H}_{2} \mathrm{O}$, as in the measurement of $\mathrm{pH}$ ), and the content of heavy metals ( $\mathrm{Cu}, \mathrm{Ni}, \mathrm{Pb}, \mathrm{Zn})$ were all defined in soil, sludge, and compost as well as in the aboveground parts of plants. The indication of heavy metals was conducted on an atomic absorption spectrophotometer after prior mineralization of samples in concentrated mineral acids. Content diversity of the studied metals in substrata and plant biomass was evaluated with the application of the non-parametric Kruskal-Wallis one-way analysis of variance by ranks.

\section{Research Results and Discussion}

Materials used (sludge and compost) had a simulative effect on crops. The yields obtained in substrata with the studied materials were nearly twice as high as the yields obtained in subsoil (Table 3). During the years of studies, yields in substrata with sewage sludge were very even, which could be caused by the high content of organic matter (Table 1) beneficially affecting both sorption ability of soil and its water capacity [10]. The beneficial effects of organic materials (including sewage sludge and compost) on plant yielding are confirmed by [2]. In a dose parallel to the one in the present study (20 Mg TS·ha $\left.{ }^{-1}\right)$, the growth of Miscanthus and Malvale yields was highly effective.

Despite high contamination of the sewage sludge with heavy metals, its incorporation into the soil was not a factor that would limit plant yielding (Table 3). The yield of grass in a substratum with sewage sludge was similar to the one obtained in a substratum with compost with low content of metals (Table 2). There were no signs of phytotoxic effects on plants and their yields, which allows for a positive assessment of the grass mixture usefulness in phytoremediation of soils contaminated with heavy metals. The exceptional tolerance of grassland communities to the presence of xenobiotics in soil was emphasized in their studies by [8]. When explaining the mechanism of high immunity of grass to the contamination of soil with metals, it is indicated that there is very limited translocation of metals from roots to shoots of grass [11].

During the years of the experiment, in all its variants, the share of grass in the sward was decreasing, while the share of other species (mainly herbs and weeds) was growing. In the group of grasses, the most strongly decreasing share was the one of Lolium perenne, while Festuca rubra and Poa pratensis were increasing their participation. Changes of this nature were found on subsoil and on objects fertilized with sludge and compost (Table 4).

Changes of the floristic composition observed in research may be connected to the durability of species, but the phenomenon of competitiveness, found in mixed sowing, also cannot be excluded. The growing share

Table 3 . Dry matter yield $\left(\mathrm{t} \cdot \mathrm{ha}^{-1}\right)$.

\begin{tabular}{|c|c|c|c|c|c|c|c|}
\hline \multirow{2}{*}{ Substrata } & \multicolumn{9}{|c|}{ Years } \\
\cline { 2 - 9 } & 2004 & 2005 & 2006 & 2007 & 2008 & 2009 & Total \\
\hline Subsoil & 3.72 & 8.46 & 9.22 & 9.82 & 7.28 & 7.92 & $\mathbf{4 6 . 4 2}$ \\
\hline Subsoil with sewage sludge & 14.60 & 15.60 & 15.60 & 15.60 & 15.92 & 13.06 & $\mathbf{9 0 . 3 8}$ \\
\hline Subsoil with compost & 8.30 & 17.08 & 16.46 & 12.80 & 14.84 & 11.06 & $\mathbf{8 0 . 5 4}$ \\
\hline
\end{tabular}


Table 4. Botanical composition of the sward in tested mixtures (\%).

\begin{tabular}{|c|c|c|c|c|c|c|}
\hline \multirow{2}{*}{ Species } & \multicolumn{6}{|c|}{ Years } \\
\hline & 2004 & 2005 & 2006 & 2007 & 2008 & 2009 \\
\hline \multicolumn{7}{|c|}{ Subsoil } \\
\hline Festuca arundinacea & 44.6 & 46.4 & 48.2 & 49.2 & 39.6 & 35.8 \\
\hline Festuca rubra & 12.9 & 14.7 & 15.2 & 16.3 & 19.6 & 20.5 \\
\hline Lolium perenne & 24.8 & 20.9 & 14.7 & 11.1 & 4.1 & 4.6 \\
\hline Poa pratensis & 15.1 & 17.2 & 18.2 & 18.8 & 26.1 & 27.3 \\
\hline Other & 2.6 & 0.8 & 3.7 & 4.6 & 10.6 & 11.8 \\
\hline \multicolumn{7}{|c|}{ Subsoil with sewage sludge } \\
\hline Festuca arundinacea & 46.7 & 43.2 & 43.8 & 45.4 & 29.7 & 29.6 \\
\hline Festuca rubra & 21.4 & 16.7 & 18.7 & 20.7 & 25.4 & 26.7 \\
\hline Lolium perenne & 10.9 & 23.7 & 19.8 & 12.5 & 5.6 & 5.9 \\
\hline Poa pratensis & 20.1 & 14.8 & 16.4 & 19.8 & 37.9 & 31.2 \\
\hline Other & 0.9 & 1.6 & 1.3 & 1.6 & 1.4 & 6.6 \\
\hline \multicolumn{7}{|c|}{ Subsoil with green waste compost } \\
\hline Festuca arundinacea & 44.9 & 46.4 & 47.5 & 48.4 & 36.1 & 34.2 \\
\hline Festuca rubra & 14.2 & 14.9 & 15.8 & 17.1 & 26.2 & 27.3 \\
\hline Lolium perenne & 22.8 & 20.9 & 14.7 & 11.1 & 5.4 & 5.1 \\
\hline Poa pratensis & 16.8 & 17.3 & 19.7 & 21.3 & 24.8 & 25.6 \\
\hline Other & 1.3 & 0.5 & 2.3 & 2.1 & 7.5 & 7.8 \\
\hline
\end{tabular}

*Other species: Trifolium repens, Chenopodium album, Medicago luplina, Elymus repens, Polygonum aviculare, Bromus mollis, Poa аппиа

of Poa pratensis in the sward, in all studied substrata, confirms the high ability of persistence of the species. The decreasing share of Lolium perenne in the sward shows the short life of this grass species [12].
The dose of sewage sludge and green waste compost applied in subsoil did not cause significant differences in the content of heavy metals in the subsoil. Only in the case of copper and its content in the substratum, where the

Table 5. The average content of heavy metals in substrata and grass biomass.

\begin{tabular}{|c|c|c|c|c|c|}
\hline \multirow[b]{2}{*}{ Metals } & \multirow[b]{2}{*}{ Substrata } & \multicolumn{2}{|c|}{ Content in substratum } & \multicolumn{2}{|c|}{ Content in biomass } \\
\hline & & Average & $\begin{array}{l}\text { Standard } \\
\text { deviation }\end{array}$ & Average & $\begin{array}{l}\text { Standard } \\
\text { deviation }\end{array}$ \\
\hline \multirow{3}{*}{$\begin{array}{c}\mathrm{Cu} \\
(\mathrm{mg} \mathrm{kg} \mathrm{TS})\end{array}$} & Subsoil & $13.7^{\mathrm{ab}}$ & 3.5 & $9.1^{\mathrm{a}}$ & 2.3 \\
\hline & Subsoil with sewage sludge & $17.2^{\mathrm{a}}$ & 1.5 & $16.0^{\mathrm{a}}$ & 3.6 \\
\hline & Subsoil with compost & $12.5^{\mathrm{b}}$ & 2.8 & $10.8^{\mathrm{a}}$ & 4.4 \\
\hline \multirow{3}{*}{$\begin{array}{c}\mathrm{Ni} \\
(\mathrm{mg} \mathrm{kg} \mathrm{TS})\end{array}$} & Subsoil & $11.3^{\mathrm{a}}$ & 6.4 & $4.4^{\mathrm{b}}$ & 2.6 \\
\hline & Subsoil with sewage sludge & $19.7^{\mathrm{a}}$ & 11.5 & $17.8^{\mathrm{a}}$ & 6.0 \\
\hline & Subsoil with compost & $9.4^{\mathrm{a}}$ & 1.9 & $6.9^{\mathrm{ab}}$ & 4.7 \\
\hline \multirow{3}{*}{$\begin{array}{c}\mathrm{Pb} \\
(\mathrm{mg} \mathrm{kg} \mathrm{TS})\end{array}$} & Subsoil & $13.2^{\mathrm{a}}$ & 5.4 & $1.7^{\mathrm{a}}$ & 2.8 \\
\hline & Subsoil with sewage sludge & $12.5^{\mathrm{a}}$ & 8.5 & $6.2^{\mathrm{a}}$ & 8.2 \\
\hline & Subsoil with compost & $12.7^{\mathrm{a}}$ & 8.4 & $3.5^{\mathrm{a}}$ & 5.2 \\
\hline \multirow{3}{*}{$\begin{array}{c}\mathrm{Zn} \\
(\mathrm{mg} \mathrm{kg} \mathrm{TS})\end{array}$} & Subsoil & $61.3^{\mathrm{a}}$ & 22.5 & $33.6^{\mathrm{b}}$ & 4.4 \\
\hline & Subsoil with sewage sludge & $84.2^{\mathrm{a}}$ & 36.3 & $60.9^{\mathrm{a}}$ & 23.0 \\
\hline & Subsoil with compost & $60.2^{\mathrm{a}}$ & 19.8 & $41.1^{\mathrm{ab}}$ & 9.0 \\
\hline
\end{tabular}


Table 6. Total (over a six-year period) heavy metals uptake of plants with yield.

\begin{tabular}{|c|c|c|c|c|}
\hline \multirow{2}{*}{ Substrata } & \multicolumn{4}{|c|}{ Removal of metals with yield $\left(\mathrm{kg} \cdot \mathrm{ha}^{-1}\right)$} \\
\cline { 2 - 5 } & $\mathrm{Cu}$ & $\mathrm{Ni}$ & $\mathrm{Pb}$ & $\mathrm{Zn}$ \\
\hline Subsoil & 0.42 & 0.20 & 0.08 & 1.56 \\
\hline Subsoil with sewage sludge & 1.44 & 1.61 & 0.56 & 5.50 \\
\hline Subsoil with compost & 0.87 & 0.56 & 0.28 & 3.31 \\
\hline
\end{tabular}

sewage sludge had been used, was decidedly higher than in the substratum with green waste compost (Table 5). The nursery experiment conducted by [13] revealed that only $10-30 \%$ of sludge share in the soil mass had a significant influence on heavy metals content in the substrata prepared in such a manner.

The plants of the lawn mixture in substratum with the addition of sewage sludge contained significantly higher content of nickel and zinc than the plants growing in subsoil. Also, the compost contributed to the increased content of these metals in plants (Table 5). As revealed by [3], sprouts of grass accumulate only small amounts of metals, but their roots contain as much as $80-90 \%$ of metals absorbed by plants from substratum with sewage sludge. The highest rates of heavy metals translocation from roots to shoots was obtained by researchers in the case of copper and zinc. In our studies, we found decidedly higher (compared to other metals) translocation of nickel and zinc into grass shoots as well as their content in shoots. The high ratio of zinc translocation from roots to shoots has also been confirmed by [11].

The uptake of heavy metals by plants showing their removal from substrata varied (Table 6). High productivity of the studied grasses, achieved on the substrata enriched with sewage sludge and green waste compost, allowed for a significant reduction in the amount of metals incorporated into substrata. The highest removal of metals was recorded in the variant with the addition of sewage sludge, where higher loads of metals had been incorporated into the soil in comparison to the one with green waste compost. The lowest removal of metals was found in the variant of grass cultivation on subsoil. The differences in the uptake between particular variants of the experiment corresponded with the loads of heavy metals incorporated into substratum together with sewage sludge and green waste compost (Tables 2 and 6).

The results of our research confirm the high tolerance of grasses on substratum contamination with heavy metals, and their high productivity on substrata enriched with organic matter, which predisposes them to be used for soil cleanup via phytoextraction. Particular predisposition of Festuca arundinacea and Poa pratensis for phytoextraction of metals from contaminated soils, cultivated in a grass mixture used in the present experiment, was also noticed by [14].

\section{Conclusions}

1. Using sewage sludge and green waste compost to enrich subsoil (poor clayey sand) had a beneficial effect on the yielding of Festuca arundinacea lawn mixture, where it nearly doubled the yield in the substratum with sewage sludge.

2. High heavy metals content $(\mathrm{Cu}, \mathrm{Ni}, \mathrm{Pb}$, and $\mathrm{Zn})$ in sewage sludge did not impair the growth nor the development of plants, which allows for positive assessment of the grass mixture usefulness in phytoremediation of soil.

3. The uptake of heavy metals from soil, showing their removal, was proportional to their content in substratum, with zinc removal being the highest.

4. The high productivity of the studied grass mixture allowed for a significant reduction of heavy metals incorporated into lawn substrata with sewage sludge and compost.

\section{References}

1. CIEPIELA G., JANKOWSKA J., JANKOWSKI K. The efficacy of mineral and organic nitrogen in fertilization of meadow sward. Fragm. Agron., 29 (2), 17, 2012 [In Polish].

2. OCIEPA-KUBICKA A., PACHURA P. The Use of Sewage Sludge and Compost for Fertilization of Energy Crops on the Example of Miscanthus and Virginia Mallow. Annual Set The Environment Protection, 15, 2267, 2013 [In Polish].

3. DMOCHOWSKI G., GAJKOWSKA-STEFAŃSKA L., DMOCHOWSKA A., PRESNAROWICZ R.K. Application of heavy metals speciation in assessing suitability of municipal post-fermentation sludge for producing roll-out grass. Przegląd Naukowy - Inżynieria i Kształtowanie Środowiska, 53, 207, 2011 [In Polish].

4. KAZANOWSKA J., SZACIŁO J. Analysis of the quality of sewage sludge and possibility of its natural utilisation. Acta Agrophysica, 19 (2), 343, 2012 [In Polish].

5. ANTONKIEWICZ J., JASIEWICZ Cz. The influence of various sludge-and-ash and peat-and-ash mixtures on yield quantity and quality of a mixture of grasses with bird's foot trifoil. Biuletyn Instytutu Hodowli i Aklimatyzacji Roślin, 234, 227, 2004 [In Polish].

6. CZYŻ H., KITCZAK T. Suitability of some grass mixtures sown on various substrates containing ash and organic matter for lawns. Zesz. Nauk. Uniw. Zielona Góra, 133, 68, 2007 [In Polish].

7. CZYŻ H., KITCZAK T. Usefulness of grass species and waste materials for the recultivation of ash-slung dumps. Zesz. Probl. Post. Nauk Rol., 518, 45, 2007 [In Polish]. 
8. BARYŁA R., SAWICKA J., KULIK M., LIPEŃSKA H. Content of components in some grass species irrigated with purified sewage. J. Elementol., 14 (1), 5, 2009.

9. KITCZAK T., CZYŻ H., KIEPAS-KOKOT A. Possibilities of organic waste utilisation as a source of organic matter in the construction of lawn. Annual Set The Environment Protection, 14, 407, 2012 [In Polish].

10. KWIATKOWSKA-MALINA J., MACIEJEWSKA A. The influence of organic matter on heavy metals uptake by radish and fhacelia. Ochrona Środowiska i Zasobów Naturalnych, 40, 217, 2009 [In Polish].

11. BARAN A., JASIEWICZ CZ. The toxicity content of zinc and cadmium in soil to different plant species. Ochrona Środowiska i Zasobów Naturalnych, 40, 157, 2009 [In Polish].
12. WRÓBEL B., JANKOWSKA-HUFLEJT H., ZASTAWNY J. Persistence and yielding of fodder grasses in phenologically differentiated meadow mixtures. Biuletyn Instytutu Hodowli i Aklimatyzacji Roślin, 225, 53, 2003 [In Polish].

13. WIŚNIEWSKA B., KALEMBASA S. The influence of waste activated sludge doses on the content and uptake $\mathrm{Zn}$, $\mathrm{Cu}$ and $\mathrm{Cr}$ by italian ryegrass biomass and acumulatiom these metals in soil. Inżynieria Ekologiczna, 27, 229, 2011 [In Polish].

14. BOSIACKI M., ZIELEZIŃSKI Ł. Phytoextraction of nickel by selected species of lawn grasses from substrates contaminated with heavy metals. Acta Sci. Pol., Hortorum Cultus, 10 (3), 155, 2011. 